\title{
Obesity induced during sexual maturation is linked to LDL-triacylglycerols in Yucatan miniature swine
}

\author{
Sylvain P. Sébert ${ }^{1}$, Gérard Lecannu ${ }^{1}$, Sandrine Sené ${ }^{1}$, Séverine Hucteau ${ }^{1}$, Maud Chetiveaux ${ }^{2}$, \\ Khadija Ouguerram ${ }^{2}$ and Martine M.-J. Champ ${ }^{1,2 *}$ \\ ${ }^{1}$ Human Nutrition and Gut Functions Unit, National Institute of Agronomic Research Rue de la Géraudière, BP 71627, 44316 Nantes \\ Cedex 3, France \\ ${ }^{2}$ Human Nutrition Research Centre, CHU Hôtel Dieu Nantes, 1 place Alexis Ricordeau, 44093 Nantes Cedex 1, France
}

(Received 8 July 2004 - Revised 2 January 2005 - Accepted 1 March 2005)

\begin{abstract}
The incidence of childhood obesity is rising dramatically throughout industrialised countries. To evaluate and study the impact of childhood obesity on lipoprotein metabolism, we developed a new animal model of premature obesity. Yucatan mini-pigs aged 4 months were studied over a 12-month period from childhood to adulthood. Animals were divided into two groups: the first group were overfed a Western misbalanced diet; the second group were normally fed a recommended human-type diet. Cholesterol and triacylglycerol concentrations in VLDL-, LDL- and HDL-lipoproteins were followed from baseline to adulthood by fast protein liquid chromatography. At 10 (the end of sexual maturation) and 16 months old (adulthood), liver, visceral and subcutaneous adipose tissues were sampled. Real-time RT-PCR was performed in order to compare apo AI, apo B, apo C-III, PPAR- $\alpha$, insulin receptor and lipoprotein lipase gene expression between groups and ages. Differences between groups were observed only after sexual maturity. Adult overfed mini-pigs had a higher LDL-cholesterol:HDL-cholesterol ratio $(P<0.05 ; 0.55$ (SE 0.06$)$ for overfed $v$. 0.42 (SE 0.04$)$ for normally fed pigs at the tenth month of the study). In both groups, VLDL-triacylglycerol decreased $(P<0 \cdot 05)$. VLDL-triacylglycerol evolution in the overfed group was associated with an increase in LDL-triacylglycerol plasma concentrations $(P<0 \cdot 05)$ after sexual maturation. LDL-triacylglycerol concentration in overfed mini-pigs went from an average of $0.28 \mathrm{mmol} / 1$ before sexual maturation to reach an average concentration of $0.56 \mathrm{mmol} / 1$ afterwards. This phenomenon has never been observed in similar studies when obesity is induced in adult mini-pigs and may represent a specific hallmark of an obesity induced during sexual maturity.
\end{abstract}

Obesity: Childhood: Adulthood: Lipoproteins: Mini-pigs

Epidemiological studies of children and adolescents have revealed a constant increase in the prevalence of overweight and obesity in industrial (Rolland-Cachera et al. 2002; Jolliffe, 2004) and in developing (Yajnik, 2004) countries. It is, however, too early to measure the long-term consequences of obesity acquired during development and puberty on individuals' health.

Adult obesity, especially central obesity (Klesges et al. 1992; Maffeis et al. 2002), is universally recognised as an independent risk factor for CVD (Han et al. 1997). A cluster of modifications in lipid metabolism associated with obesity are linked to CVD risk (Ginsberg, 2000). The quantity and the quality of plasma lipoprotein in relation to triacylglycerols and cholesterol ester distribution in VLDL, LDL and HDL could reveal early events in the deregulation of lipid metabolism. Several pathways are involved in lipid synthesis and transport, including liver PPAR- $\alpha$ and insulin signalling pathways, lipoprotein lipase content and activity, and modifications of specific lipid transfer proteins: cholesteryl ester transfer protein (CETP) and phospholipid transfer protein (Ren et al. 1996; Desvergne et al. 1998; Fruchart, 2001). Both cellular and plasma effectors are involved in the control of lipoprotein synthesis, lipid release and uptake through apo and lipogenic enzyme synthesis and are known to be modified by the Western lifestyle (a high-fat, high glycaemic index diet, low physical activity, etc.) and obesity (Vu-Dac et al. 1994).

As in adulthood, the Western lifestyle during childhood can promote lipid disorders (Franklin et al. 1998). Compared with their normal-weight counterparts, obese children and adolescents frequently have higher LDL-cholesterol concentrations and lower HDL-cholesterol plasma levels (Franklin et al. 1998, Plourde, 2002), and are at risk of developing triacylglycerolaemia (Hayashibe et al. 1997). Moreover, some data from statistical analyses suggest that early obesity could have an impact on adulthood obesity and increase the risk of developing a metabolic syndrome leading to CVD in adulthood (Dietz, 1998; Freedman et al. 1999). Continuous obesity can serve as a generator for prolonged insulin resistance (Vanhala et al. 1998). Other authors have, however, reported conflicting results and suggest that childhood obesity does not have an adverse effect on adult health (Wright et al. 2001; Maffeis et al. 2002). Children and adolescents are, by definition, not mature. Interestingly, as with the case of adult obesity, the hormonal changes that occur during puberty are associated with natural modifications of lipid metabolism (Kouda et al. 
2003) and insulin sensitivity (Moran et al. 1999). Nevertheless, very little has until now been known about the cumulative effects of obesity, a Western lifestyle and puberty on lipid metabolism.

Studies of the evolution of body weight during obesity and lipoprotein profiles (quantity and quality) during and after sexual maturation would be helpful to better understand childhood obesity and its long-term consequences. This implies a need for longitudinal and interventional studies with a strict control of food intake from childhood to adulthood. To provide an alternative to such long and invasive experiments, we have developed a mini-pig model with obesity induced before sexual maturation and until adulthood.

Adult mini-pigs have already been used to study insulin resistance and lipid metabolism changes in relation to the Western lifestyle (Phillips et al. 1982; Gerrity et al. 2001). Even if pigs and mini-pigs, compared with man, have a very low activity of CETP and present low triacylglycerol plasma concentrations (Larsen et al. 2002; Olsen et al. 2002), compared with mice and rats, pigs and mini-pigs represent one of the species most relevant for modelling lipoprotein metabolism in man. Indeed, pigs are, like man, recognised as an LDL species (Olsen et al. 2002), and they transport a large part of their esterified cholesterol in this lipoprotein. Pigs are also omnivorous (Phillips et al. 1982), their cardiovascular system is quite similar to that of man (Dixon et al. 1999), and their human-like physiology (Moughan et al. 1992) and physiopathology related to obesity, type 2 diabetes and CVD (Dixon et al. 1999), as well as their large size, are very useful for mimicking the situation of obese people. The objective of the present study was to observe possible specific lipid-lipoprotein modulation in relation to the development of obesity induced during sexual maturation in a Yucatan mini-pig model of childhood obesity.

\section{Material and methods}

Animals

Non-castrated male Yucatan mini-pigs (n 10; Yucatan micropig; IFFA-Credo-Charles River, Dardilly, France) aged 4 months were used in this study. Before the experiments, the mini-pigs were acclimated for 2 weeks to their local environment: natural light/dark cycle, a temperature-controlled room $\left(20-24^{\circ} \mathrm{C}\right)$, individual feeding boxes and free access to water. All experimental treatments were in accordance with French legislation on animal experimentation (Decree $87-848$ of the French Penal Code, 1987).

\section{Experimental design}

The mini-pigs were divided into two identical groups of five animals: the first group was overfed (OF; 1.5 times the recommended energy intake for mini-pigs; Bollen et al. 1999) a Western-type diet, and the second one was normally fed (NF) a recommended human diet (Table 1). This study was conducted from mini-pig 'childhood' (4 months old \pm 1 week) to adulthood (16 months old \pm 1 week), the first 6-month period studied corresponding to the mini-pigs' sexual maturation (sexual maturity being between 7 and 10 months of age). The mini-pigs were fed twice per day. Both diets had identical energy densities of $18 \mathrm{MJ} / \mathrm{kg}$ DM. The OF diet was designed to provide $1818 \mathrm{~kJ} /$ body weight $^{0.75}$ per $24 \mathrm{~h}$, and the NF diet $1212 \mathrm{~kJ} /$ body
Table 1. Composition of NF (normally fed) and OF (overfed) diets

\begin{tabular}{|c|c|c|}
\hline & NF diet & OF diet \\
\hline Energy intake ( $\mathrm{kJ} /$ body weight $\mathrm{t}^{0.75}$ perd) & 1212 & 1818 \\
\hline \multicolumn{3}{|l|}{ Energy distribution (\% total energy) } \\
\hline Carbohydrates & 50 & 53 \\
\hline Starch & 90 & 90 \\
\hline Sugar & 10 & 10 \\
\hline Fat & 35 & 37 \\
\hline Saturated fatty acids & 30 & 50 \\
\hline MUFA & 50 & 30 \\
\hline PUFA & 20 & 20 \\
\hline$n-6 / n-3$ & $9 \cdot 2$ & 0 \\
\hline Protein ${ }^{*}$ & 15 & 10 \\
\hline \multicolumn{3}{|l|}{ Nutrients ( $g / 100 \mathrm{~g} \mathrm{DM})$} \\
\hline Sucrose & 3.58 & - \\
\hline Glucose & - & $5 \cdot 39$ \\
\hline Dry instant mashed potatoes & - & $71 \cdot 22$ \\
\hline Ground wheat (whole grain) & $70 \cdot 75$ & - \\
\hline Butter & - & $12 \cdot 91$ \\
\hline Coconut oil & 3.05 & 0.29 \\
\hline Sunflower margarine & - & $4 \cdot 19$ \\
\hline Olive oil & 11.53 & - \\
\hline Soyabean oil & $1 \cdot 19$ & - \\
\hline Casein & $6 \cdot 56$ & 3.50 \\
\hline Vitamin mix* & $2 \cdot 15$ & 0.80 \\
\hline \multirow[t]{2}{*}{ Mineral mix ${ }^{*}$} & 1.08 & 1.60 \\
\hline & 0.10 & 0.09 \\
\hline
\end{tabular}

*Vitamins, minerals and proteins have been reduced in the OF diet to provide the same amount $(\mathrm{g} / \mathrm{kg})$ as for NF.

For details of diets and procedures, see p. 282

weight $^{0.75}$ per $24 \mathrm{~h}$. During sexual maturation, the amount of food distributed to the groups was adjusted each week. After sexual maturity (10 months old), the amount of food distributed to pigs was then maintained at a constant level. Throughout the entire study, food distribution for OF pigs was calculated on the basis of the mean metabolic weight (body weight ${ }^{0.75}$ ) of NF pigs. Food distribution to the NF group was calculated on the basis of their individual body weights.

\section{Lipid measurements}

Blood was taken via the anterior vena cava from overnight-fasted pigs at baseline and after 4, 6, 8, 10 and 12 months of treatment. For lipoprotein cholesterol and triacylglycerol levels, plasma samples $(200 \mu 1)$ were analysed by fast protein liquid chromatography (Amersham Pharmacia Biotech Inc., Orsay, France) on two Superose 6HR 10/30 columns (Amersham Pharmacia Biotech Inc.) and eluted with a saline buffer $(0.15 \mathrm{~mol} / \mathrm{l} \mathrm{NaCl}, 1 \mathrm{mmol} / \mathrm{l}$ EDTA, $0.02 \% \mathrm{NaN}_{3}, \mathrm{pH} 8.2$ ). The absorbance of the eluent was continuously monitored at $280 \mathrm{~nm}$ using a UV monitor. Fast protein liquid chromatography was programmed to collect elution volumes ranging from $11.40 \mathrm{ml}$ to $35.70 \mathrm{ml}$, which represented eighty-one fractions of $300 \mu \mathrm{l}$ and included the three lipoprotein fractions: VLDL (elution volume 12.9-15.9 ml), LDL (elution volume $18.9-24.0 \mathrm{ml}$ ) and HDL (elution volume $26.4-32.4 \mathrm{ml}$ ). All the fractions were assayed for cholesterol and triacylglycerol concentrations determined by enzymatic procedures (cholesterol: RTU; triacylglycerol: PAP 1000; BioMerieux, Lyon, France).

\section{Gene expression}

Tissues samplings were made under general anaesthesia with a gaseous mix of $\mathrm{O}_{2}$, nitrogen protoxyde and isoflurane (Centravet; 
La Milière, Plancoët, France). At sexual maturity and adulthood, liver, subcutaneous and visceral adipose tissues were sampled. Every sample was taken under RNase-free conditions for quantitative RT-PCR. Total RNA was extracted from samples according to the Chomczynski and Sacchi method (Chomczynski \& Sacchi, 1987) by using TRIzol reagent (Invitrogen, Cergy Pontoise, France). DNase treatments (RQ1 Dnase; Promega, Charbonniere, France) were performed on each extract to eliminate traces of DNA, and reverse transcription was made with $2 \mu \mathrm{g}$ total RNA with the superscript II RT (Invitrogen). Quantitative gene expression was measured with a quantitative thermocycler (BioRad, Marnes-La-Coquette, France) in which complementary DNA amplification was detected with the Quantitec SYBR green PCR kit (Qiagen S.A., Courtaboeuf, France). Reactions were compared with the $18 \mathrm{~S}$ ribosomal RNA. Gene expressions of apo B, apo A-I, apo C-III, PPAR- $\alpha$ and insulin receptor were measured in liver. In adipose tissues, the expression of the gene encoding for lipoprotein lipase (LPL) was quantified. Quantitative gene expressions were measured by using the $2^{-\partial \mathrm{CT}}$ method in which $\mathrm{\partial CT}$ was the cycle threshold difference between housekeeping genes and a defined gene in each sample determined at an arbitrary threshold established at 25. Gene expressions were expressed as relative values, taking the mean expression of a gene at sexual maturity in the NF pig group as a reference value (1.00) for each gene. To compare gene expression in visceral and subcutaneous adipose tissues, the mean NF pig group value of each gene in the visceral adipose tissue at sexual maturity was used as a reference.

\section{Statistical analysis}

Data were recorded as mean with their standard errors. Statistical analyses were made with Staview software (SAS Institute, Boston, MA, USA) in order to perform Student's $t$ tests, $P<0.05$ representing a significant difference.

\section{Results}

\section{Body weight evolutions}

Figure 1 presents the evolution in body weight of the mini-pigs during the 12-month study period. In both groups, average body weight increased $(P<0 \cdot 01)$. Average NF body weights after 6 , 10 and 12 months of the experiment were 3.0, $4 \cdot 4$ and $4 \cdot 6$ times higher than initial NF body weights, respectively. In OF minipigs, at the same points in time, body weights were 5.5, 8.4 and 9.0 times higher than baseline body weights, respectively. After 4 months of feeding treatments ( 8 months old), NF mini-pigs were approximately twice as lean as the OF animals $(P<0 \cdot 01)$.

\section{Cholesterol measurements}

Total cholesterol, VLDL-cholesterol, LDL-cholesterol and HDLcholesterol plasma concentrations throughout the study are shown in Table 2. In both groups, cholesterol concentrations doubled $(P<0.01)$ during the first 4 months of the study and then remained stable until the end of the study. In NF mini-pigs, VLDL-cholesterol plasma concentrations were unchanged from baseline to the tenth month of the study. The VLDL-cholesterol concentration in NF animals after 12 months of study was lower than baseline concentration $(P<0 \cdot 05)$. In the NF group,

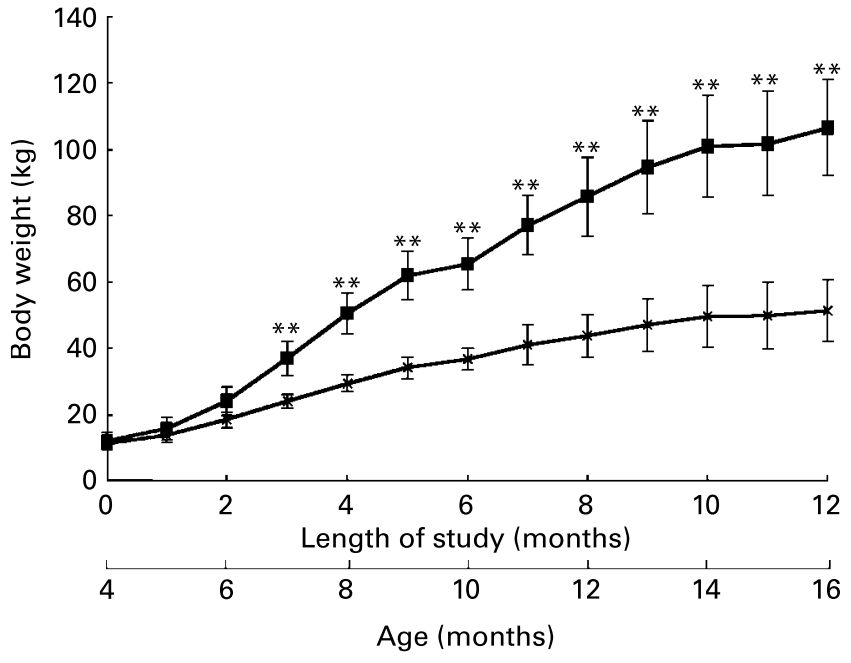

Fig. 1. Evolution of normally fed $(-x-)$ and overfed (-) pig body weight. Mean values were significantly different between groups, ${ }^{\star *} P<0.01$. For details of diets and procedures, see p. 282.

LDL-cholesterol plasma concentrations increased from baseline to the fourth month of the study $(P<0.05)$, but the subsequent measurements did not show any significant differences compared with baseline concentrations. The increase in total cholesterol in $\mathrm{NF}$ pigs was characterised by the significant increase in HDLcholesterol from the fourth month $(P<0.05)$. In OF mini-pigs, changes in cholesterol profile were characterised by a decrease in VLDL-cholesterol after the sixth month of the study (10 months old $)(P<0.05)$, a higher LDL-cholesterol level at 4,6 and 10 months of study compared with baseline $(P<0.05)$ and an increase in HDL-cholesterol from the fourth month of the study $(P<0.05)$. We did not observe any significant differences related to cholesterol concentration between groups. Only the LDL-cholesterol:HDL-cholesterol ratio (Fig. 2) differed between $\mathrm{NF}$ and $\mathrm{OF}$ animals, with a decrease of this ratio in NF minipigs from the eighth month until the end of the study $(P<0.05)$, whereas this ratio remained stable and significantly higher in the $\mathrm{OF}$ animals than in the NF animals $(P<0 \cdot 05)$.

\section{Triacylglycerol measurements}

The evolution of fasting total triacylglycerol concentrations and distributions between fast protein liquid chromatography lipoproteins are presented in Table 3. Compared with baseline values, fasting triacylglycerol concentrations remained statistically unchanged in the NF group. In this group, compared with total and VLDL-triacylglycerol concentrations measured after 6 months' treatment, we measured significant decreases in these triacylglycerol determinants after 8,10 and 12 months of study $(P<0 \cdot 05)$. LDL- and HDL-triacylglycerol were unchanged throughout the study in NF animals. In OF mini-pigs, baseline total and VLDL-triacylglycerol were significantly higher than the concentrations measured at 4, 8, 10 and 12 months of study $(P<0.05)$. In OF animals, LDL-triacylglycerol concentrations remained stable during sexual maturation (i.e. from baseline to the sixth month of the study) and increased thereafter $(P<0 \cdot 05)$. In OF mini-pigs, HDL-triacylglycerol plasma concentration presented a tendency to increase after sexual maturity without presenting significant differences compared with baseline HDL-triacylglycerol concentrations. 
Table 2. Evolution of cholesterol concentrations measured by fast protein liquid chromatography in normally fed (NF) and overfed (OF) mini-pigs

\begin{tabular}{|c|c|c|c|c|c|c|c|c|c|}
\hline & & & & \multicolumn{6}{|c|}{ Cholesterol (mmol/l) } \\
\hline & & \multicolumn{2}{|c|}{ Total } & \multicolumn{2}{|c|}{ VLDL } & \multicolumn{2}{|c|}{ LDL } & \multicolumn{2}{|c|}{ HDL } \\
\hline & & Mean & SE & Mean & SE & Mean & SE & Mean & SE \\
\hline \multirow[t]{2}{*}{ Baseline } & NF & $1 \cdot 66^{\mathrm{a}}$ & 0.23 & $0.046^{a}$ & 0.019 & $0.69^{a}$ & 0.22 & 0.92 & 0.10 \\
\hline & OF & $1 \cdot 70^{\mathrm{a}}$ & 0.26 & $0.050^{\mathrm{a}}$ & 0.015 & $0.70^{\mathrm{a}}$ & 0.12 & $0.94^{\mathrm{a}}$ & 0.22 \\
\hline \multirow[t]{2}{*}{4 months ${ }^{*}$} & NF & $3.73^{b}$ & 0.44 & $0.061^{a}$ & 0.023 & $1 \cdot 16^{\mathrm{b}}$ & 0.14 & $2.50^{b}$ & 0.3 \\
\hline & OF & $3.59^{b}$ & 0.78 & $0.041^{a}$ & 0.018 & $1 \cdot 20^{b}$ & 0.29 & $2 \cdot 33^{b}$ & 0.50 \\
\hline \multirow[t]{2}{*}{6 months $\dagger$} & $\mathrm{NF}$ & $3.45^{\mathrm{b}}$ & 0.06 & $0.037^{a}$ & 0.009 & $0.98^{a}$ & 0.14 & $2 \cdot 43^{b}$ & 0.11 \\
\hline & OF & $3.07^{b}$ & 0.42 & $0.019^{b}$ & 0.008 & $1.06^{b}$ & 0.22 & $1.99^{b}$ & 0.25 \\
\hline \multirow[t]{2}{*}{8 monthsł } & NF & $2 \cdot 87^{\mathrm{b}}$ & 0.17 & $0.029^{a}$ & 0.014 & $0.77^{\mathrm{a}}$ & 0.08 & $2.06^{b}$ & 0.14 \\
\hline & OF & $2 \cdot 57^{a, b}$ & 0.76 & $0.018^{b}$ & 0.011 & $0.89^{a}$ & 0.19 & $1.65^{b}$ & 0.55 \\
\hline \multirow[t]{2}{*}{10 months§ } & NF & $3.35^{b}$ & 0.44 & $0.032^{\mathrm{a}}$ & 0.014 & $0.96^{a}$ & 0.06 & $2 \cdot 35^{\mathrm{b}}$ & 0.39 \\
\hline & OF & $2 \cdot 71^{b}$ & 0.62 & $0.018^{b}$ & 0.015 & $1 \cdot 17^{b}$ & 0.45 & $1 \cdot 74^{\mathrm{b}}$ & 0.43 \\
\hline \multirow[t]{2}{*}{12 months $\|$} & NF & $2 \cdot 47^{c, b}$ & 0.42 & $0.007^{\mathrm{b}}$ & 0.003 & $0.66^{a}$ & 0.10 & $1 \cdot 80^{\mathrm{b}}$ & 0.3 \\
\hline & OF & $2 \cdot 86^{b}$ & 0.63 & $0.022^{b}$ & 0.010 & $0.93^{a}$ & 0.18 & $1.91^{\mathrm{b}}$ & 0.46 \\
\hline
\end{tabular}

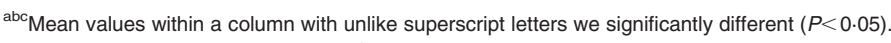

* 4 months: between 3 and 4 months of experimental treatment.

† 6 months: between 5 and 6 months of experimental treatment.

78 months: between 7 and 8 months of experimental treatment.

$\S 10$ months: between 9 and 10 months of experimental treatment.

II 12 months: between 11 and 12 months of experimental treatment.

Few significant differences have been observed between groups for triacylglycerol measurements. VLDL-triacylglycerol at 4 months of the study was higher in NF than in OF pigs $(P<0.05)$, and HDL-triacylglycerol at 6 months of the study was higher in NF than $\mathrm{OF}$ animals $(P<0 \cdot 05)$. These differences were selective changes, the only significant differences that lasted between groups being observed for LDL-triacylglycerol concentration. LDL-triacylglycerol plasma concentrations were about twice as low in the NF group as in the OF group after 8 $(P=0.03), 10(P=0.052)$ and 12 months of study $(P=0.02)$.

\section{Liver gene expression}

Liver gene expressions measured at the end of sexual maturation and adulthood are shown in Table 4. At the end of sexual maturation (10 months old, 6 months of study), NF mini-pigs had

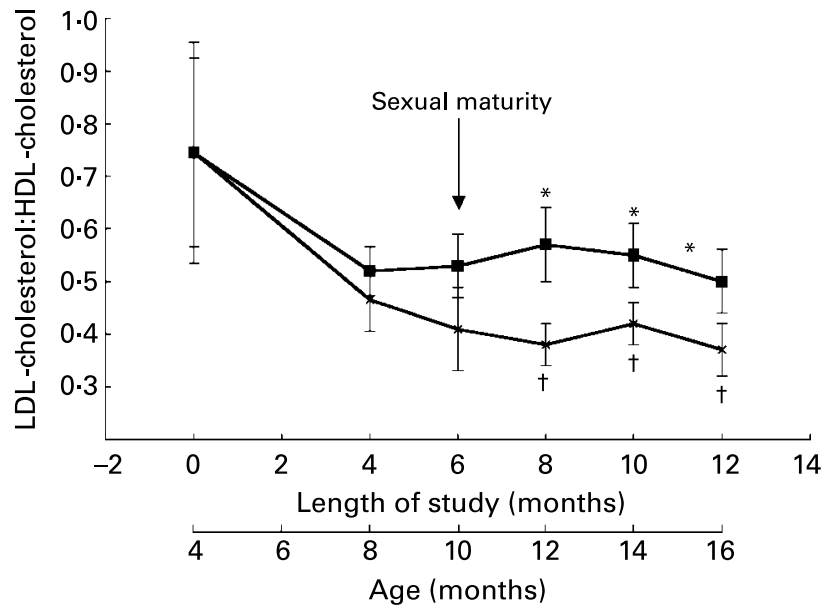

Fig. 2. Evolution of LDL-cholesterol:HDL-cholesterol ratio in normally fed $(-X-)$ and overfed (-) mini-pigs from baseline (time 0$)$ to adulthood (time 12). Mean values were significantly different between groups, ${ }^{\star} P<0.05$. Mean values were significantly different between baseline in a group, $\dagger P<0.05$. For details of diets and procedures, see p. 282 higher apo A-I gene expression than OF animals $(P<0 \cdot 05)$. The other gene expressions measured at that time did not differ between groups. After 12 months of study (adulthood), all liver gene expressions measured in NF mini-pigs decreased $(P<0.05)$ compared with the end of sexual maturation. In OF adult minipigs, only PPAR- $\alpha$ and insulin receptor gene expressions decreased between 6 (sexual maturity) and 12 months of study (adulthood; $P<0 \cdot 05$ ). Apo C-III, apo B and apo A-I remained stable from 6 months of study to the end. After 12 months of study, apo B gene expression measured in NF adult mini-pigs was significantly lower than in OF mini-pigs $(P<0 \cdot 05)$.

\section{Lipoprotein lipase gene expression}

Comparisons of visceral and subcutaneous adipose tissue LPL gene expression are presented in Fig. 3. No difference was observed between groups. After 6 months of study, mini-pig LPL gene expression was higher in visceral adipose tissue than in subcutaneous tissue $(P<0 \cdot 05)$. Between the sixth and twelfth months of the study, LPL gene expression in subcutaneous adipose tissues increased significantly in both groups $(P<0.05)$ and reached the same level as visceral LPL gene expression.

\section{Discussion}

The objective of the present study was to characterise possible changes in lipoprotein profile during the development of obesity induced during childhood. For this purpose, immature male Yucatan miniature pigs were overfed a Western-type diet enriched with saturated fat and high glycaemic index carbohydrates. These were compared with control animals that were fed a balanced humantype diet providing an adequate daily energy intake for these animals. The tracking of obesity until adulthood allowed us to model a putative impact of the development of an obesity during childhood on lipid metabolism. As expected, overfeeding mini-pigs with a Western-type diet dramatically increased body weight, and the growth curve of the NF mini-pigs did not differ 
Table 3. Evolution of triacylglycerol concentrations measured by fast protein liquid chromatography in normally fed (NF) and overfed (OF) mini-pigs

\begin{tabular}{|c|c|c|c|c|c|c|c|c|c|}
\hline & & & & \multicolumn{6}{|c|}{ Triacylglycerols (mmol/l) } \\
\hline & & \multicolumn{2}{|c|}{ Total } & \multicolumn{2}{|c|}{ VLDL } & \multicolumn{2}{|c|}{ LDL } & \multicolumn{2}{|c|}{ HDL } \\
\hline & & Mean & SE & Mean & SE & Mean & SE & Mean & SE \\
\hline \multirow[t]{2}{*}{ Baseline } & $\mathrm{NF}$ & $0.20^{\mathrm{a}}$ & 0.06 & $0 \cdot 142^{a}$ & 0.066 & $0.036^{\mathrm{a}}$ & 0.022 & $0.022^{\mathrm{a}}$ & 0.017 \\
\hline & OF & $0 \cdot 20^{\mathrm{a}}$ & 0.06 & $0 \cdot 180^{\mathrm{a}}$ & 0.061 & $0.019^{a}$ & 0.005 & $0.005^{a}$ & 0.002 \\
\hline \multirow{2}{*}{4 months } & $\mathrm{NF}$ & $0.28^{a}$ & 0.11 & $0.230^{\mathrm{a}}$ & 0.099 & $0.041^{a}$ & 0.008 & $0.014^{a}$ & 0.005 \\
\hline & OF & $0 \cdot 12^{\mathrm{b}, \star \star}$ & 0.03 & $0.079^{\mathrm{b}, * *}$ & 0.019 & $0.039^{a}$ & 0.014 & $0.003^{a}$ & 0.005 \\
\hline \multirow[t]{2}{*}{6 months } & $\mathrm{NF}$ & $0.23^{a}$ & 0.04 & $0 \cdot 171^{a}$ & 0.027 & $0.031^{a}$ & 0.013 & $0.025^{\mathrm{a}}$ & 0.007 \\
\hline & OF & $0.17^{\mathrm{a}}$ & 0.03 & $0.138^{a}$ & 0.025 & $0.027^{\mathrm{a}}$ & 0.012 & $0.003^{\mathrm{a}, \star \star}$ & 0.004 \\
\hline \multirow[t]{2}{*}{8 months } & $\mathrm{NF}$ & $0.14^{a}$ & 0.03 & $0 \cdot 109^{a}$ & 0.033 & $0.024^{\mathrm{a}}$ & 0.006 & $0.010^{\mathrm{a}}$ & 0.004 \\
\hline & OF & $0 \cdot 14^{a}$ & 0.03 & $0.067^{b}$ & 0.025 & $0.058^{\mathrm{b}, \star \star}$ & 0.020 & $0.019^{a}$ & 0.012 \\
\hline \multirow[t]{2}{*}{10 months } & $\mathrm{NF}$ & $0.11^{a}$ & 0.05 & $0.075^{\mathrm{a}}$ & 0.037 & $0.026^{a}$ & 0.013 & $0.009^{a}$ & 0.005 \\
\hline & OF & $0.18^{\mathrm{a}}$ & 0.06 & $0.093^{b}$ & 0.035 & $0.062^{b, * *}$ & 0.025 & $0.027^{\mathrm{a}}$ & 0.021 \\
\hline \multirow[t]{2}{*}{12 months } & $\mathrm{NF}$ & $0 \cdot 10^{\mathrm{a}}$ & 0.04 & $0.066^{\mathrm{a}}$ & 0.030 & $0.017^{\mathrm{a}}$ & 0.009 & $0.013^{a}$ & 0.010 \\
\hline & OF & $0 \cdot 11^{b}$ & 0.03 & $0.051^{b}$ & 0.023 & $0.045^{\mathrm{b}, * *}$ & 0.004 & $0.014^{a}$ & 0.008 \\
\hline
\end{tabular}

${ }^{\mathrm{ab}}$ Mean values within a column with unlike superscript letters were significantly different $(P<0.05)$.

${ }^{\star *} P \leq 0.05$ between groups.

from the standard growth curve for Yucatan micropigs (Bollen et al. 1999). Compared with similar experiments performed on post sexually mature Gottingen mini-pigs with quite similar nutritional treatment (Johansen et al. 2001; Larsen et al. 2002), we observed higher weight gains in the OF mini-pigs used in the present experiment. Gottingen and Yucatan micropigs have very proximal growth curves and body weights at same ages (Bollen et al. 1999). As a consequence, we may suppose that the greater weight gain observed in our OF Yucatan mini-pigs resulted from the fact that obesity was induced during a growing period.

In the present experiment, we chose to compare the effects of overfeeding with a Western-type diet with the effects of a recommended human-type diet. The NF experimental diet was identical to the OF diet in relation to its energy density and was not the standard low-fat animal diet commonly used in similar experiments. Our observations of NF and OF mini-pigs were very similar to those of high-fat treated mini-pigs in related experiments (Dixon et al. 1999, Larsen et al. 2002). As previously observed in pigs fed a human-type diet (with a recommended fat ratio in the diet; Mahley et al. 1975), our data suggest that the total fat intake, rather than the energy intake or the quality of fatty acids, could have induced an increase in total cholesterol. As a consequence, the comparison of two human-type diets did not make it possible for us to define total cholesterol as a benchmark of obesity, as is frequently the case in other animal models. Nevertheless, even if total cholesterol increased in a similar way in both groups, the NF diet enriched with monounsaturated fats, as has been observed in man (Luscombe et al. 1999; Gill et al. 2003), may have induced the fall in the HDL-cholesterol:LDL-cholesterol ratio (Luscombe et al. 1999).

It is interesting to note that both groups shared common features. In fact, we observed similar changes in cholesterol, PPAR- $\alpha$ and apo A-1 gene expressions and in total and VLDL-triacylglycerol between sexual maturity and adulthood. Finally, with the exception of body weight, nothing differentiated the groups of mini-pigs before the end of sexual maturation, and significant differences were observed only between the end of sexual maturation and adulthood. On the one hand, we may suppose that the length of time between baseline and sexual maturity is insufficient to involve lipid metabolism in the case of the OF treatment. Nevertheless, the length of numerous nutritional studies on animals and man has been shorter than our first experimental period, suggesting that lipid modifications could have appeared (Dixon et al. 1999; Luscombe et al. 1999). On the other hand, lipid metabolism is known to be naturally modified during development and puberty in human adolescents (Kouda et al. 2003) and may counteract the effect of the OF nutritional treatment. These changes are still poorly understood and are probably caused by modifications in growth and sex hormones during puberty (Youssef et al. 2002). Observations made in healthy subjects show increases in cholesterol and triacylglycerol concentrations through the Tanner stages, followed by decreases (Kouda et al. 2003). In the present

Table 4. Liver gene expressions in sexually mature and adult normally fed (NF) and overfed (OF) mini-pigs

\begin{tabular}{|c|c|c|c|c|c|c|c|c|c|c|c|c|}
\hline & \multicolumn{5}{|c|}{ Six months of study } & \multicolumn{5}{|c|}{ Twelve months of study } & & \\
\hline & \multicolumn{4}{|c|}{10 months old } & & \multicolumn{4}{|c|}{16 months old } & \multirow[b]{3}{*}{$P$} & & \\
\hline & \multicolumn{2}{|c|}{ NF } & \multicolumn{2}{|c|}{ OF } & \multirow[b]{2}{*}{$P$} & \multicolumn{2}{|c|}{ NF } & \multicolumn{2}{|c|}{ OF } & & \multicolumn{2}{|c|}{ Age } \\
\hline & Mean & SE & Mean & SE & & Mean & SE & Mean & SE & & NF & OF \\
\hline Apo A-I & 1.00 & 0.09 & 0.50 & 0.13 & $<0.05$ & 0.68 & 0.09 & 0.69 & 0.19 & NS & $<0.05$ & NS \\
\hline Apo B & 1.00 & 0.32 & 0.93 & 0.37 & NS & 0.37 & 0.07 & 0.58 & 0.13 & $<0.05$ & $<0.05$ & NS \\
\hline Apo C-III & 1.00 & 0.35 & 0.77 & 0.45 & NS & 0.26 & 0.07 & 0.34 & 0.14 & NS & $<0.05$ & NS \\
\hline Insulin receptor & 1.00 & 0.07 & 0.84 & 0.09 & NS & 0.43 & 0.07 & 0.54 & $0 \cdot 13$ & NS & $<0.05$ & $<0.05$ \\
\hline PPAR- $\alpha$ & 1.00 & 0.13 & 0.70 & 0.25 & NS & & & & & NS & $<0.05$ & $<0.05$ \\
\hline
\end{tabular}




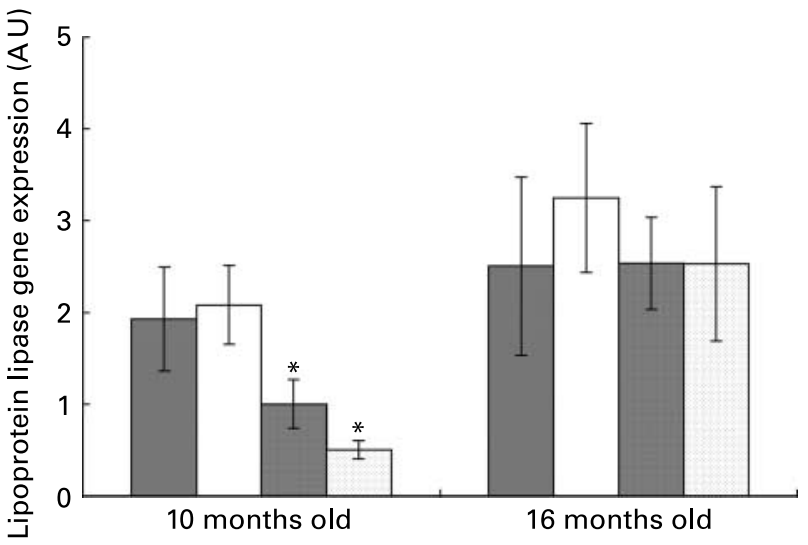

Fig. 3. Visceral and subcutaneous adipose tissue lipoprotein lipase quantitative gene expressions measured in normally fed (NF) and overfed (OF) mini-

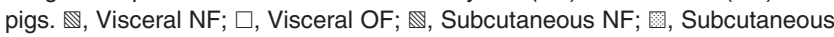
OF. AU, arbitrary unit. Mean values were significantly different between adipose tissues, ${ }^{*} P<0.05$. For details of diets and procedures, see p. 282

study, it appears that the change in total cholesterol, HDL-cholesterol, total triacylglycerol and VLDL-triacylglycerol throughout sexual maturation may also be linked to development. Furthermore, changes in PPAR- $\alpha$ and apo A-I supported this hypothesis and may partially explain cholesterol modifications (Vu-Dac et al. 1994) between sexual maturity and adulthood.

The lack of triacylglycerol increases in obese mini-pigs has frequently been observed (Larsen et al. 2002). It appears to be specific to pigs, associated with the fact that pigs, compared with other mammals, have ample LPL activity and higher de novo adipose lipogenesis (Vernon et al. 1999). However, in the present study, we observed that total triacylglycerol and VLDLtriacylglycerol decreased in both groups after sexual maturity. This suggests that, at this stage, the decrease in total triacylglycerol is a natural phenomenon for pigs. This observation was associated with increased LPL gene expression in subcutaneous adipose tissues between sexual maturity and adulthood. Even if proteins were not quantified, these results, according to theoretical LPL functions (Takahashi et al. 2003), especially in subcutaneous adipose tissue (Nicklas et al. 2000), may suggest an increase in fat storage in mini-pigs after sexual maturity, leading to the observed drop in total triacylglycerol level.

Although total triacylglycerol decreased in both groups, the drop in VLDL-triacylglycerol plasma concentrations in OF mini-pigs was associated with an increase in LDL-triacylglycerol and higher VLDL-cholesterol concentrations compared with NF pigs. In OF mini-pigs, after sexual maturity, HDL-triacylglycerol increased and HDL-cholesterol decreased, except for the 12-month treatment. These results could suggest the stimulation of CETP activity, an enzyme known in man to mediate the exchange of esterified cholesterol and triacylglycerol between VLDL and LDL and HDL (Ginsberg, 2000). Such an increase in CETP activity is linked to obesity in adults (Arai et al. 1994) and adolescents (Asayama et al. 2002). Little is known about this protein in pigs. Its gene has been cloned (Shi et al. 2002), but its activity is very low in pig plasma compared with man (Ha \& Barter, 1982; Pussinen et al. 1997). Our data suggest that CETP could be activated in OF mini-pigs. In man, increased CETP activity and the resulting LDL-triacylglycerol is recognised as a risk factor for CVD (Lahdenpera et al. 1996). Indeed, LDL-triacylglycerol is associated with small and dense
LDL (Ginsberg, 2000). This LDL sub-fraction has a lower affinity for the LDL receptor (Galeano et al. 1998) and presents a higher oxidability (Guerin et al. 2001). Both of these factors are involved in the development of atherosclerosis.

An increase in LDL-triacylglycerol concentrations related to similar high-fat feeding was never observed in studies carried out on adult mini-pig models (Dixon et al. 2002). This observation suggests that the increase in LDL-triacylglycerol observed in the present study may represent a specific phenomenon that occurs during growth. As frequently observed in obese adolescents, OF mini-pigs were taller than NF mini-pigs (data not shown), supporting the fact that obesity induced before sexual maturity could have stimulated growth factors. It is interesting to note that patients with growth defects such as acromegaly or growth hormone deficiency have high risks of CVD associated with modifications of LDL sub-fractions (Tan et al. 1997; Carrilho et al. 2001). Little is known about the effect of growth hormone and/or insulin-like growth factor-1 on LDL metabolism. Few studies have shown interactions between growth factors and the LDL receptor (Machado et al. 2003), CETP (Carrilho et al. 2001) or IL-6 (De Benedetti et al. 2002). According to the links existing between growth defects and LDL metabolism, we may hypothesise that obesity induced during sexual maturation was able to induce growth factors (growth hormone and/or insulin-like growth factor-1) modifications, which could in turn induce the increase in LDL-triacylglycerol. Furthermore, obese adolescents are frequently taller than normal-weight adolescents (Heude et al. 2003; Freedman et al. 2004) and insulin-like growth factor-1 plasma concentrations are higher in obese adolescents (Wabitsch et al. 1996).

In conclusion, the present study investigated the impact of the development of obesity during sexual maturation on lipid metabolism in a Yucatan mini-pig model. Very small changes in lipoprotein profile and gene expressions were observed in this study. First, lipid metabolism was not modified until the end of puberty in our mini-pigs. Nevertheless, after sexual maturation, we detected a possible specific benchmark of this form of obesity induced during sexual maturation. Indeed, plasma LDL-triacylglycerol concentration increased in obese miniature swine. Such an increase in LDL-triacylglycerol concentrations had never been observed in mini-pigs in which obesity was induced in adulthood. Moreover, observations of acromegalic and growth hormone-deficient patients illustrate possible relationships between growth and LDL metabolism. To our knowledge, the present study, on Yucatan mini-pigs, is the first investigation of changes in lipid metabolism during obesity induced during growth. It has been performed on a small number of immature male Yucatan mini-pigs and needs to be confirmed on female and other strains of mini-pig. It suggests, however, that childhood obesity could specifically modify the metabolism of LDL.

\section{Acknowledgements}

The authors would like to express their gratitude to D. Mésangeau and L. Noah from Merck-Santé S.A (Centre de Recherche de Chilly-Mazarin, Chilly-Mazarin, France) for their financial and scientific contributions. We also thank the Régions Pays de la Loire and Bretagne for their financial support. Finally, we would like to thank C. Bonnet for his technical assistance for gene transcription measurements and G. Poupeau and J.L. Lescure for taking care of the mini-pigs. 


\section{References}

Arai T, Yamashita S, Hirano K, et al. (1994) Increased plasma cholesteryl ester transfer protein in obese subjects. A possible mechanism for the reduction of serum HDL cholesterol levels in obesity. Arterioscler Thromb 14, 1129-1136.

Asayama K, Hayashibe H, Dobashi K, Uchida N, Nakane T, Kodera K \& Shirahata A (2002) Increased serum cholesteryl ester transfer protein in obese children. Obes Res 10, 439-446.

Bollen JA, Hansen AK \& Rasmussen HJ (2000) The laboratory swine. Boca Raton, FL: CRC Press.

Carrilho AJ, Cunha-Neto MB, Nunes VS, Lottenberg AM, Medina WL, Nakandakare ER, Musolino NR, Bronstein MD \& Quintao EC (2001) Plasma cholesteryl ester transfer protein and lipoprotein levels during treatment of growth hormone-deficient adult humans. Lipids 36, 549-554.

Chomczynski P \& Sacchi N (1987) Single-step method of RNA isolation by acid guanidinium thiocyanate-phenol-chloroform extraction. Anal Biochem 162, 156-159.

De Benedetti F, Meazza C \& Martini A (2002) Role of interleukin-6 in growth failure: an animal model. Horm Res 58, Suppl 1, 24-27.

Desvergne B, IJPenberg A, Devchand PR \& Wahli W (1998) The peroxisome proliferator-activated receptors at the cross-road of diet and hormonal signalling. J Steroid Biochem Mol Biol 65, 65-74.

Dietz WH (1998) Childhood weight affects adult morbidity and mortality. J Nutr 128, 411S-414S

Dixon JL, Shen S, Vuchetich JP, Wysocka E, Sun GY \& Sturek M (2002) Increased atherosclerosis in diabetic dyslipidemic swine: protection by atorvastatin involves decreased VLDL triglycerides but minimal effects on the lipoprotein profile. J Lipid Res 43, 1618-1629.

Dixon JL, Stoops JD, Parker JL, Laughlin MH, Weisman GA \& Sturek M (1999) Dyslipidemia and vascular dysfunction in diabetic pigs fed an atherogenic diet. Arterioscler Thromb Vasc Biol 19, 2981-2992.

Franklin FA Jr, Dashti N \& Franklin CC (1998) Evaluation and management of dyslipoproteinemia in children. Endocrinol Metab Clin North Am 27, 641-654.

Freedman DS, Dietz WH, Srinivasan SR \& Berenson GS (1999) The relation of overweight to cardiovascular risk factors among children and adolescents: the Bogalusa Heart Study. Pediatrics 103, $1175-1182$.

Freedman DS, Khan LK, Serdula MK, Dietz WH, Srinivasan SR \& Berenson GS (2004) Inter-relationships among childhood BMI, childhood height, and adult obesity: the Bogalusa Heart Study. Int J Obes Relat Metab Disord 28, 10-16.

Fruchart JC (2001) Peroxysome proliferator-activated receptor-alpha activation and high-density lipoprotein metabolism. Am J Cardiol 88, 24-29.

Galeano NF, Al-Haideri M, Keyserman F, Rumsey SC \& Deckelbaum RJ (1998) Small dense low density lipoprotein has increased affinity for LDL receptor-independent cell surface binding sites: a potential mechanism for increased atherogenicity. J Lipid Res 39, 1263-1273.

Gerrity RG, Natarajan R, Nadler JL \& Kimsey T (2001) Diabetes-induced accelerated atherosclerosis in swine. Diabetes 50, 1654-1665.

Gill JM, Brown JC, Caslake MJ, Wright DM, Cooney J, Bedford D, Hughes DA, Stanley JC \& Packard CJ (2003) Effects of dietary monounsaturated fatty acids on lipoprotein concentrations, compositions, and subfraction distributions and on VLDL apolipoprotein B kinetics: dosedependent effects on LDL. Am J Clin Nutr 78, 47-56.

Ginsberg HN (2000) Insulin resistance and cardiovascular disease. J Clin Invest 106, 453-458.

Guerin M, Le Goff W, Lassel TS, Van Tol A, Steiner G \& Chapman MJ (2001) Atherogenic role of elevated CE transfer from HDL to VLDL(1) and dense LDL in type 2 diabetes: impact of the degree of triglyceridemia. Arterioscler Thromb Vasc Biol 21, 282-288.

Ha YC \& Barter PJ (1982) Differences in plasma cholesteryl ester transfer activity in sixteen vertebrate species. Comp Biochem Physiol B 71, $265-269$.
Han TS, Richmond P, Avenell A \& Lean ME (1997) Waist circumference reduction and cardiovascular benefits during weight loss in women. Int J Obes Relat Metab Disord 21, 127-134.

Hayashibe H, Asayama K, Nakane T, Uchida N, Kawada Y \& Nakazawa S (1997) Increased plasma cholesteryl ester transfer activity in obese children. Atherosclerosis 129, 53-58.

Heude B, Lafay L, Borys JM, Thibult N, Lommez A, Romon M, Ducimetiere P \& Charles MA (2003) Time trend in height, weight, and obesity prevalence in school children from Northern France. Diabetes Metab 29, 235-240.

Johansen T, Hansen HS, Richelsen B \& Malmlof R (2001) The obese Gottingen minipig as a model of the metabolic syndrome: dietary effects on obesity, insulin sensitivity, and growth hormone profile. Comp Med 51, $150-155$.

Jolliffe D (2004) Extent of overweight among US children and adolescents from 1971 to 2000. Int J Obes Relat Metab Disord 28, 4-9.

Klesges RC, Klesges LM, Haddock CK \& Eck LH (1992) A longitudinal analysis of the impact of dietary intake and physical activity on weight change in adults. Am J Clin Nutr 55, 818-822.

Kouda K, Nakamura H, Fan W \& Takeuchi H (2003) Negative relationships between growth in height and levels of cholesterol in puberty: a 3-year follow-up study. Int J Epidemiol 32, 1105-1110.

Lahdenpera S, Syvanne M, Kahri J \& Taskinen MR (1996) Regulation of low-density lipoprotein particle size distribution in NIDDM and coronary disease: importance of serum triglycerides. Diabetologia 39, 453-461.

Larsen MO, Rolin B, Wilken M, Carr RD \& Svendsen O (2002) High-fat high-energy feeding impairs fasting glucose and increases fasting insulin levels in the Gottingen minipig: results from a pilot study. Ann N Y Acad Sci 967, 414-423.

Luscombe ND, Noakes M \& Clifton PM (1999) Diets high and low in glycemic index versus high monounsaturated fat diets: effects on glucose and lipid metabolism in NIDDM. Eur J Clin Nutr 53, 473-478.

Machado MO, Hirata RD, Hirata MH, Hirszel P, Sellitti DF \& Doi SQ (2003) Growth hormone increases low-density lipoprotein receptor and HMG-CoA reductase mRNA expression in mesangial cells. Nephron Exp Nephrol 93, e134-e140.

Maffeis C, Moghetti P, Grezzani A, Clementi M, Gaudino R \& Tato L (2002) Insulin resistance and the persistence of obesity from childhood into adulthood. J Clin Endocrinol Metab 87, 71-76.

Mahley RW, Weisgraber KH, Innerarity T, Brewer HB Jr \& Assmann G (1975) Swine lipoproteins and atherosclerosis. Changes in the plasma lipoproteins and apoproteins induced by cholesterol feeding. Biochemistry 14, 2817-2823.

Moran A, Jacobs DR Jr, Steinberger J, Hong CP, Prineas R, Luepker R \& Sinaiko AR (1999) Insulin resistance during puberty: results from clamp studies in 357 children. Diabetes 48, 2039-2044.

Moughan PJ, Birtles MJ, Cranwell PD, Smith WC \& Pedraza M (1992) The piglet as a model animal for studying aspects of digestion and absorption in milk-fed human infants. World Rev Nutr Diet 67, 40-113.

Nicklas BJ, Ferrell RE, Rogus EM, Berman DM, Ryan AS, Dennis KE \& Goldberg AP (2000) Lipoprotein lipase gene variation is associated with adipose tissue lipoprotein lipase activity, and lipoprotein lipid and glucose concentrations in overweight postmenopausal women. Hum Genet 106, 420-424.

Olsen AK, Bladbjerg EM, Marckmann P, Larsen LF \& Hansen AK (2002) The Gottingen minipig as a model for postprandial hyperlipidaemia in man: experimental observations. Lab Anim 36, 438-444.

Phillips RW, Panepinto LM, Spangler R \& Westmoreland N (1982) Yucatan miniature swine as a model for the study of human diabetes mellitus. Diabetes 31, 30-36.

Plourde G (2002) Impact of obesity on glucose and lipid profiles in adolescents at different age groups in relation to adulthood. BMC Fam Pract 3, 18.

Pussinen PJ, Olkkonen VM, Jauhiainen M \& Ehnholm C (1997) Molecular cloning and functional expression of cDNA encoding the pig plasma phospholipid transfer protein. J Lipid Res 38, 1473-1481. 
Ren B, Thelen A \& Jump DB (1996) Peroxisome proliferator-activated receptor alpha inhibits hepatic S14 gene transcription. Evidence against the peroxisome proliferator-activated receptor alpha as the mediator of polyunsaturated fatty acid regulation of s14 gene transcription. $J$ Biol Chem 271, 17167-17173.

Rolland-Cachera MF, Castetbon K, Arnault N, Bellisle F, Romano MC, Lehingue Y, Frelut ML \& Hercberg S (2002) Body mass index in 7-9-y-old French children: frequency of obesity, overweight and thinness. Int J Obes Relat Metab Disord 26, 1610-1616.

Shi XW, Zhang YD, Rothschild MF \& Tuggle CK (2002) Rapid communication: genetic linkage and physical mapping of the porcine cholesteryl ester transfer protein (CETP) gene. J Anim Sci 80, 1390-1391.

Takahashi T, Hirano T, Okada K \& Adachi M (2003) Apolipoprotein CIII deficiency prevents the development of hypertriglyceridemia in streptozotocin-induced diabetic mice. Metabolism 52, 1354-1359.

Tan KC, Shiu SW, Janus ED \& Lam KS (1997) LDL subfractions in acromegaly: relation to growth hormone and insulin-like growth factor-I. Atherosclerosis 129, 59-65.

Vanhala M, Vanhala P, Kumpusalo E, Halonen P \& Takala J (1998) Relation between obesity from childhood to adulthood and the metabolic syndrome: population based study. BMJ 317, 319.
Vernon RG, Barber MC \& Travers MT (1999) Present and future studies on lipogenesis in animals and human subjects. Proc Nutr Soc 58, $541-549$.

Vu-Dac N, Schoonjans K, Laine B, Fruchart JC, Auwerx J \& Staels B (1994) Negative regulation of the human apolipoprotein A-I promoter by fibrates can be attenuated by the interaction of the peroxisome proliferator-activated receptor with its response element. J Biol Chem 269 , 31012-31018.

Wabitsch M, Blum WF, Muche R, Heinze E, Haug C, Mayer H \& Teller W (1996) Insulin-like growth factors and their binding proteins before and after weight loss and their associations with hormonal and metabolic parameters in obese adolescent girls. Int $J$ Obes Relat Metab Disord 20, 1073-1080.

Wright CM, Parker L, Lamont D \& Craft AW (2001) Implications of childhood obesity for adult health: findings from thousand families cohort study. BMJ 323, 1280-1284.

Yajnik CS (2004) Early life origins of insulin resistance and type 2 diabetes in India and other Asian countries. J Nutr 134, 205-210.

Youssef AA, Valdez R, Elkasabany A, Srinivasan SR \& Berenson GS (2002) Time-course of adiposity and fasting insulin from childhood to young adulthood in offspring of parents with coronary artery disease: the Bogalusa Heart Study. Ann Epidemiol 12, 553-559. 